\title{
The Impact of Economic Turbulence on Local Bank Efficiency: Does Common Wisdom Hold?
}

\author{
Felisitas Defung ${ }^{\# 1}$, Rizky Yudaruddin ${ }^{\# 2}$, Syarifah Hudayah ${ }^{\# 3}$ \\ Faculty of Economics and Business, Mulawarman University \\ JL. Tanah Grogot Kampus Gn Kelua Samarinda, INDONESIA \\ ${ }^{1}$ felisitas.defungefeb.unmul.ac.id \\ ${ }^{2}$ rizky. yudaruddinefeb. unmul.ac.id \\ ${ }^{3}$ syarifah.hudayahefeb.unmul.ac.id
}

\begin{abstract}
Common theory suggests that banking performance is positively related to economic growth. This common wisdom in this paper is further tested by investigating whether economic turmoil has a meaningful impact on local bank technical efficiency. This study uses Regional Development Banks (RDB)data in Indonesia as a case study during 2005 to 2015 . The analysis is conducted using two stage approaches in which Data Envelopment Analysis (DEA) is used in the first stage, whilst in the second stage pooled OLS regression is employed. The findings show that most of local banks are technically inefficient throughout the period of analysis. Furthermore, the results indicate that crisis tends to have a significant effect, while the rest of the variables show various level of magnitude on local bank efficiency.
\end{abstract}

Keywords: efficiency, data envelopment analysis, banks

\section{BACKGROUND}

Regional Development Banks (RDB) - known as Bank Pembangunan Daerah (BPD) in Indonesia -, have been increasingly pivotal to strengthen local economy in respected region (or provinces) which in turn, influences the national economy as a whole. Theories tend to dictate that the financial institution's performance is positively related to the economic growth ([21] [20]). Similarly, when the local economy performs well, the banking sector, especially those that operated in the respected region will automatically affected. This is because the turnover of the economy will boost the financial activities then increase revenue of financial institution, including banks. The relationship and the effect also can run vice versa.

This paper examines the efficiency of Regional Development Bank group, consists of 26 banks) in Indonesia during the period of 2005 to 2015. A nonparametric technique using data envelopment analysis (DEA) is employed to analysed the 26 RDBs.
Research shows that, the efficiency of regional development banks of Indonesia mostly falls behind compare to its counterpart such as state banks, private national banks and foreign banks (see [16] [10], [15]) These results have drawn some serious concern due to the authority and 'privilege-status' that this group held in the industry. For instance; firstly, this group ranks third in the whole banking industry in Indonesia for holding third party fund or public fund ([16] and [15]). Secondly, RDB is generally, by default, given an authority to hold and manage local government budget fund in their respected region. Thirdly, historically, none of the bank from this group have been closed by the government due to their poor performance.

Questions about the underperformance of RDB compare to its counterpart domestic banks such as national-non-foreign-exchange banks is critical to observe. This study is going to analysis whether economics condition, either at the national level and local level, able to explain the cause of variation in RDB efficiency. Moreover, considering the world economy nowadays is connected due to rapid development in information technology, the analysis also includes the turbulence in recent world economy.

A number of empirical studies on bank efficiency and productivity present various result, however research related to the Indonesian case is relatively few, particularly concerning the RDB group. Some studies scholarly studies in Indonesia case such as [24], [17]; [11] and [22].

The rest of this paper is organized as follows: the next section present data and methodology in section 2. Section 3 presents the empirical results 
and discussion for first stage and second stage. Section 4 concludes the article.

\section{DATA AND Methodology}

An easy way to comply with the conference paper formatting requirements is to use this document as a template and simply type your text into it.

The data set consists of 10 (ten) annual observation during the period of 2005 to 2015 for each Regional Development Bank. This study includes the $26 \mathrm{RDBs}$ in Indonesia and data is collected from the individual RDB financial statement report published by the Indonesian Central Bank (Bank Indonesia).

Specifying the inputs and the outputs variable to calculate technical efficiency is very critical on the outcome ([8] and [27]). Two popular methods in banking efficiency study that common to set the inputs and outputs are intermediation approach and production approach ([4]). The intermediation approach considers mainly on the role of banks in channelling the funds from depositors to borrowers, whilst production approach focuses on production centre for depositors and borrowers. Following Berger and Humphrey [4], this study use intermediation approach to determine the variables ${ }^{1}$.

We select three variable inputs and two variable outputs. The three inputs are deposit, employee expenses and operational expenses, while the two outputs are loan and operational revenue. The relative efficiency of bank then calculated using DEA method. The DEA method was pioneering by [13], which further developed by [6], for CRS assumption [2] for VRS assumption.

The input-oriented DEA is employed as follows:

$$
\operatorname{Min}_{\theta, \lambda} \theta_{\text {, }}
$$

Subject to $-y_{-}$ti $+Y \lambda \geqslant 0, \quad \theta$ x_ti-X $\lambda \geqslant 0$, $\mathrm{I}^{\prime} \lambda=1, \lambda \geq 0$

where I1 is an I x1 vector of ones. The scale efficiency is then obtained by using the fraction between TE CRS and TE VRS.

Once bank efficiency scored is obtained, the next step is to explore the variables that possibly determine the variation in the efficiency measure. [19] argues that external factors cannot be

\footnotetext{
${ }^{1}$ Intermediation approach introduced by [28]
}

accommodated directly in the DEA, they are commonly included indirectly through the so called "second-stage analysis". The external factors are important in explaining the variation in the efficiency score. Methods that commonly used to be employed in the second stage namely Tobit model ([18], [10], [5]) and ordinary least square (OLS) ([26] [1]). Following [23] this study uses OLS as below:

$$
\text { Eff } f_{f t}=f\left(X_{Q f t}, Z_{K t}, Y\right)
$$

Where $E f f_{f t}$ is the input-oriented technical efficiency of $f$-th banks in $t$-th time period; $X_{Q f t}$ is the set bank-specific variables; $Z_{K t}$ is the set of macroeconomic factors $(K)$ and $Y$ represents crisis. The main objective is to investigate the impact of economics turmoil which represented by CRISIS a dummy variable for 2008 and $2009=1$ otherwise $=$ 0, GDP growth (DGPgr) represents national economic growth, GDRP growth (GDRPgr) represents local economic growth and annual rate of inflation (INF). In addition to the external factors include four bank-specific variables namely return on assets (ROA), net interest margin (NIM), nonperforming loan (NPL) and a natural log of assets to represent bank's SIZE.

\section{EMPIRICAL RESULTS AND DISCUSSION}

\section{A. First stage analysis}

Table 1 summarizes the average of technical efficiency of the individual RDB score during the $2005-2015$ periods. The mean score is presented under each assumption used, CRS, VRS and SE. The score of technical efficiency ranges from 0 to 1 which represents the lowest to the highest efficient banks, accordingly. The results indicate that the bank relative efficiency mostly lies below the efficiency frontier ranging from the lowest $(0.76)$ to the highest (1). With regard to the assumption of return to scale, the result of VRS is shown to be consistently higher compare to CRS.

The variation of efficiency among the RDB is relatively random, in which there is no specific pattern regarding to the region of $\mathrm{RDB}$ with its performance. For instance, there are two banks, RDB of Kalimantan Timur and RDB of Sulawesi Barat, that are constantly reached the efficiency frontier with the highest score at 1 or $100 \%$ 
efficient, meaning that these banks are able to minimize the use of input to produce the output. Both of the banks are operated outside java which has been known as a more developed region than other. On the other side, the lowest score is shown for RDB Papua. Surprisingly, the RDB of Jakarta is only slightly above the lowest which the score $80 \%$ and $88 \%$ for CRS and VRS, accordingly. Similar score appears for RDB of Sumatera and Belitung.

TABLE 1

AVERAGE TECHNICAL EFFICIENCY OF RDB DURING 2005 - 2015

\begin{tabular}{|c|l|c|c|c|}
\hline NO & \multicolumn{1}{|c|}{ BANK } & CRS & VRS & SE \\
\hline 1 & BPD Aceh & 0.85 & 0.89 & 0.95 \\
\hline 2 & BPD Bali & 0.98 & 1.00 & 0.98 \\
\hline 3 & BPD Bengkulu & 0.87 & 0.91 & 0.96 \\
\hline 4 & BANK DKI (Jakarta) & 0.80 & 0.88 & 0.90 \\
\hline 5 & BPD Jambi & 0.94 & 0.97 & 0.97 \\
\hline 6 & BPD Jawa Tengah & 0.83 & 0.97 & 0.85 \\
\hline 7 & BPD Jawa Barat dan Banten, Tbk & 0.97 & 1.00 & 0.97 \\
\hline 8 & BPD Jawa Timur & 0.88 & 0.97 & 0.91 \\
\hline 9 & BPD Kalimantan Timur & 1.00 & 1.00 & 1.00 \\
\hline 10 & BPD Kalimantan Tengah & 0.88 & 0.90 & 0.98 \\
\hline 11 & BPD Kalimantan Barat & 0.77 & 0.80 & 0.96 \\
\hline 12 & BPD Kalimantan Selatan & 0.86 & 0.88 & 0.98 \\
\hline 13 & BPD Lampung & 0.96 & 0.98 & 0.98 \\
\hline 14 & BPD Maluku & 0.86 & 0.88 & 0.97 \\
\hline 15 & BPD Nusa Tenggara Barat & 0.99 & 1.00 & 0.99 \\
\hline 16 & BPD Nusa Tenggara Timur & 0.95 & 0.96 & 0.99 \\
\hline 17 & BPD Papua & 0.76 & 0.80 & 0.96 \\
\hline 18 & BPD Riau Kepri & 0.88 & 0.92 & 0.96 \\
\hline 19 & BPD Sulawesi Tenggara & 0.97 & 0.99 & 0.98 \\
\hline 20 & BPD Sulawesi Selatan dan Barat & 1.00 & 1.00 & 1.00 \\
\hline 21 & BPD Sulawesi Tengah & 0.92 & 1.00 & 0.92 \\
\hline 22 & BPD Sulawesi Utara & 0.90 & 0.96 & 0.94 \\
\hline 23 & BPD Sumatera Barat & 0.89 & 0.94 & 0.95 \\
\hline 24 & BPD Sumatera Selatan Dan Babel & 0.80 & 0.85 & 0.95 \\
\hline 25 & BPD Sumatera Utara & 0.90 & 0.96 & 0.94 \\
\hline 26 & BPD Yogyakarta & 0.87 & 0.91 & 0.96 \\
\hline
\end{tabular}

Note: BPD: Bank Pembangunan Daerah (Regional Development Bank or RDB), VRS: Variable return to scale, CRS: Constant return to Scale, and SE: Scale efficiency.

For the shake of brevity, Figure 1 presents the annual mean of technical efficiency for all bank under each assumption. The graph shows that although there is a significant drop in 2007 for both CRS and VRS, but the efficiency of bank run smoothly and less volatile toward the end of period of analysis. The average efficiency score for the whole industry during 2005-2015 is $90 \%, 94 \%$ and 95\% for CRS, VRS and SE, respectively.
Figure 1 The Average Annual Technical Efficiency of RDB 2005 - 2015

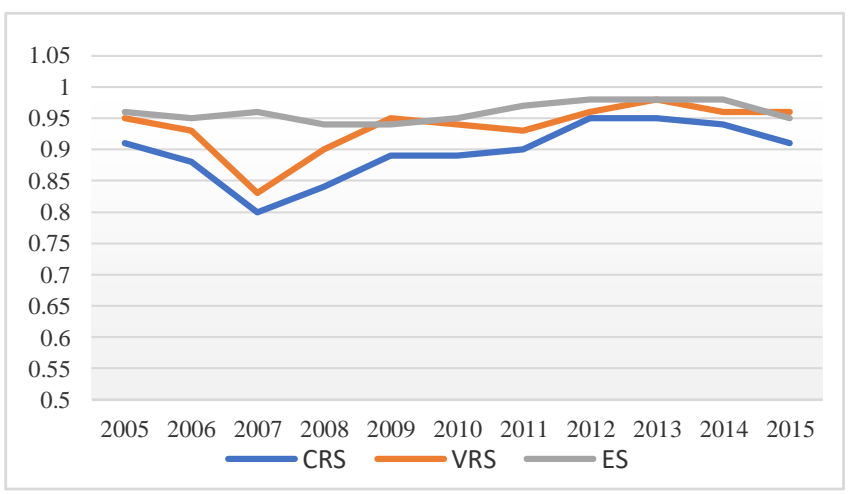

Second stage analysis

A further analysis on the determinant of efficiency is performed by using formula number 3 . Table 2 reports the regression results based on three different set of external variables (three models). We separate in regression in order to accommodate and evaluate the effect of economic condition at the national and regional (provincial) level independently. All models have a good explanatory power to explain the effect of variables. The Table reveals that the effect of macroeconomics variables varies across the regression.

The impact of CRISIS tends to be negative which confirms the common expectation that economic crisis adversely affects bank performance, although the coefficients are not statistically significant, except in model 2 of CRS. This is possibly due to the scale of operation of the RDBs that mainly not engaging directly in the international transaction.

For the macroeconomics variables, the effect of national and local economic growth tends to be statistically significant with a negative causality (Model 1 and 3). The magnitude indicates that slower economic growth is more favourable of banking efficiency at the regional level. Although it is against conventional wisdom, this result confirms the finding of [9] for the RDB analysis, but run contrary with [14]. The negative significant impact on economic growth should be explained with care. The possible explanation is the economic growth might not linearly affect the efficiency of RDBs. Similar contradiction appears on the effect if inflation in Model 1 and 3. The coefficient suggests that a high inflation condition is positively associated with higher bank efficiency. This result 
in contradicts with common studies in bank efficiency ([3], [12]) but it is in line with [14].

TABLE 2

REGRESSION RESULTS OF TECHNICAL EFFICIENCY - OLS

\begin{tabular}{|l|l|l|l|l|l|l|}
\hline \multirow{2}{*}{ Variable } & \multicolumn{2}{|c|}{ Model 1 } & \multicolumn{2}{c|}{ Model 2 } & \multicolumn{2}{c|}{ Model 3 } \\
\cline { 2 - 7 } & CRS & \multicolumn{1}{c|}{ VRS } & CRS & VRS & CRS & VRS \\
\hline Constant & $0.9627^{\text {a) }}$ & $0.7501^{\text {a) }}$ & $0.7950^{\text {a) }}$ & $0.7950^{\text {a) }}$ & $0.9617^{\text {a) }}$ & $0.7555^{\text {a) }}$ \\
\hline ROA & $0.0463^{\text {a) }}$ & $0.0396^{\text {a) }}$ & $0.0446^{\text {a) }}$ & $0.0446^{\text {a) }}$ & $0.0462^{\text {a) }}$ & $0.0399^{\text {a) }}$ \\
\hline NIM & $-0.006^{\text {c) }}$ & $-0,0031$ & $-0.0074^{\text {b) }}$ & $-0,0074$ & $-0.005^{\text {c) }}$ & $-0,0033$ \\
\hline NPL & $0.005^{\text {b) }}$ & $0.0064^{\text {a) }}$ & $0.0055^{\text {b) }}$ & $0.0055^{\text {a) }}$ & $0.005^{\text {b) }}$ & $0.0064^{\text {b) }}$ \\
\hline SIZE & $-0,0057$ & 0,0077 & 0,0007 & $0.0007^{\text {b }}$ & $-0,0057$ & 0,0073 \\
\hline CRISIS & $-0,0023$ & 0,0132 & $-0.037^{\text {b) }}$ & $-0,0375$ & - & - \\
\hline GDPgr & $-0.009^{\text {a) }}$ & $-0.006^{\text {a) }}$ & - & - & & \\
\hline INF & $0.0063^{\text {a) }}$ & $0.0051^{\text {a) }}$ & - & - & - & - \\
\hline GDRPgr & & & $6,32 \mathrm{E}-05$ & $6,32 \mathrm{E}-05$ & $-0.009^{\text {a) }}$ & $-0.006^{\text {a) }}$ \\
\hline INFReg & & & $-8,33 \mathrm{E}-05$ & $-8,33 \mathrm{E}-$ & $0.0064^{\text {a) }}$ & $0.0048^{\text {a) }}$ \\
\hline R-squared & 0,2913 & 0,2535 & 0,1834 & 0,1834 & 0,2912 & 0,2509 \\
\hline F-statistic & $16.32^{\text {a) }}$ & $13.489^{\text {a) }}$ & $8.921^{\text {a) }}$ & $8.921^{\text {a) }}$ & $19.110^{\text {a) }}$ & $15.578^{\text {a) }}$ \\
\hline Obs. & 286 & 286 & 286 & 286 & 286 & 286 \\
\hline
\end{tabular}

Note: a), b) and c) denote denote significance at the $1 \%$ level, the $5 \%$ level and the $10 \%$ level, respectively. SE is the standard error.

Turning to the internal bank specific-variables, the size of the bank does not have a meaningful effect on efficiency in all models. The rest of bank specific-variables have a convincing and statistically significant effect on bank efficiency across the models. The effect of ROA strongly suggests that a profitable bank support its higher efficiency, whilst the net interest margin ratio run contrary. Higher ratio of net interest margin tends to cause a decline in efficiency. This result supports finding of [25] in their financial efficiency case on RDB. The effect of bad loan, which represents the quality of bank assets, is opposing with common theories. The magnitude of NPL implies that a higher bad loan ratio is likely more preferable to support bank efficiency. This finding supports the claim of [9] with regard to Reginal Development Bank in revenue model.

\section{CONCLUSIONS}

This study empirically investigates the technical efficiency of regional development banks group during the period of 2005 to 2015 . DEA is used to obtain the efficiency score under CRS, VRS and SE assumption. The results on the first stage of analysis show that most of the RDB are technically inefficient where the measured are lied under the efficiency frontier. Two banks demonstrate their efficiency level are consistently reached the frontier which means that they are able to minimize the utilization of inputs to produce outputs

The result at the second stage, the economics condition present various effect of RDB's efficiency. Crisis show an unfavourable effect, but the power of magnitude is meaningless. The economic growth has a very strong power on the bank efficiency although the way of causality should be interpreted with care.

\section{REFERENCES}

[1] Ataullah, Ali, and Le Hang. (2006). "Economic Reforms and Bank Efficiency in Developing Countries: The Case of the Indian Banking Industry." Applied Financial Economics 16 (9): 653-663.

[2] Banker, R. D., A. Charnes, and W. W. Cooper. (1984). "Some Models for Estimating Technical and Scale Inefficiencies in Data Envelopment Analysis." Management Science 30 (9): 1078-1092.

[3] Barth, James R., Chen Lin, Yue Ma, Jesús Seade, and Frank M. Song. (2013). "Do Bank Regulation, Supervision and Monitoring Enhance or Impede Bank Efficiency?" Journal of Banking \& Finance 37 (8): 28792892.

[4] Berger, Allen N., and David B. Humphrey. (1997). "Efficiency of Financial Institutions: International Survey and Directions for Future Research." European Journal of Operational Research 98 (2): 175-212.

[5] Castellanos, Sara G, and Jesus Gustavo Garza-García. (2013). "Competition and Efficiency in the Mexican Banking Sector." BBVA Working Paper, Madrid 13/29

[6] Charnes, A., W. W. Cooper, and E. Rhodes. (1978). "Measuring the Efficiency of Decision Making Units." European Journal of Operational Research 2 (6): 429-444.

[7] Coelli, Tim, D.S Prasada Rao, Christopher J. O'Donnell, and George E Battese. (2005). An Introduction to Efficiency and Productivity Analysis. second ed. New York: Spinger.

[8] Das, Abhiman, and Saibal Ghosh. (2006). "Financial Deregulation and Efficiency: An Empirical Analysis of Indian Banks During the Post Reform Period." Review of Financial Economics 15(3): 193-221.

[9] Defung, Felisitas. (2014). "Impact of Banking Deregulation on Bank Efficiency and Productivity Growth: Evidence from Indonesia." Ph.D Thesis, School of Economics and Finance, Curtin University. http://hdl.handle.net/20.500.11937/288.

[10] Defung, Felisitas, Ruhul Salim, and Harry Bloch. (2016). "Has Regulatory Reform Had Any Impact on Bank Efficiency in Indonesia? A Two-Stage Analysis." Applied Economics 48 (52): 5060-5074. doi: 10.1080/00036846.2016.1170934.

[11] (2017). "Economic Liberalization and Sources of Productivity Growth in Indonesian Banks: Is It Efficiency Improvement or Technological Progress?" Applied Economics 49 (33): 3313-3327. doi: 10.1080/00036846.2016.1259748

[12] Delis, Manthos D., Philip Molyneux, and Fotios Pasiouras. (2011) "Regulations and Productivity Growth in Banking: Evidence from Transition Economies." Journal of Money, Credit \& Banking 43 (4) 735-764.

[13] Farrell, M. J. (1957). "The Measurement of Productive Efficiency." Journal of the Royal Statistical Society. Series A (General) 120 (3): 253-290.

[14] Grigorian, David A., and Vlad Manole. (2006). "Determinants of Commercial Bank Performance in Transition: An Application of Data Envelopment Analysis." Comparative Economic Studies 48 (3): 497 522.

[15] Hadad, Muliaman D., Maximilian J. B. Hall, Karligash A Kenjegalieva, Wimboh Santoso, Ricky Satria, and Richard Simper. (2008a). "Efficiency and Malmquist Indices of Productivity Change in Indonesian Banking " Discussion Paper Series; Department of Economics, Loughborough University, UK WP 2008-08. 
[16] - (2008b). "Efficiency in Indonesian Banking: Recent Evidence." Discussion Paper Series; Department of Economics, Loughborough University, UK 2008 - 13.

[17] Hadad, Muliaman D., Maximilian J. B. Hall, Karligash A. Kenjegalieva, Wimboh Santoso, and Richard Simper. (2010). "Banking Efficiency and Stock Market Performance: An Analysis of Listed Indonesian Banks." Review of Quantitative Finance and Accounting: 120.

[18] Havrylchyk, Olena. (2006). "Efficiency of the Polish Banking Industry: Foreign Versus Domestic Banks." Journal of Banking \& Finance 30 (7): 1975-1996.

[19] Hoff, Ayoe. (2007). "Second Stage Dea: Comparison of Approaches for Modelling the Dea Score." European Journal of Operational Research 181 (1): 425-435.

[20] King, Robert G., and Ross Levine. (1993). "Financial Intermediation and Economic Development." In Financial Intermediation in the Construction of Europe, ed. Colin Mayer and Xavier Vives, 156-189. London: Centre for Economic Policy Research.

[21] Levine, Ross. (1997). "Financial Development and Economic Growth: Views and Agenda." Journal of Economic Literature 35 (2): 688-726.

[22] Margono, Heru, Subhash C. Sharma, and Paul D. Melvin. (2010). "Cost Efficiency, Economies of Scale, Technological Progress and
Productivity in Indonesian Banks." Journal of Asian Economics 21 (1): 53-65.

[23] McDonald, John. (2009). "Using Least Squares and Tobit in Second Stage Dea Efficiency Analyses." European Journal of Operational Research 197 (2): 792-798.

[24] Parinduri, Rasyad A., and Yohanes E. Riyanto. (2014). "Bank Ownership and Efficiency in the Aftermath of Financial Crises: Evidence from Indonesia." Review of Development Economics 18 (1) 93-106.

[25] Permana, Yudistira Hendra, and Ike Yuli Andjani. (2014). "Financial Efficiency Performance of Regional Development Bank (Rdb) to Support Regional Economy in Indonesia." International Journal of Economic Sciences III (4)

[26] Salim, Ruhul, Mohammad Ziaul Hoquea, and Suyanto. (2010). "The Role of Governance, ICT and Bad Loans in Australian Bank Efficiency: An Empirical Study." Asia Pacific Journal of Economics \& Business 14 (1): 18-36

[27] Sathye, Milind. (2001). "X-Efficiency in Australian Banking: An Empirical Investigation." Journal of Banking \& Finance 25 (3): 613 630.

[28] Sealey, C. W., and James T. Lindley. (1977). "Inputs, Outputs, and a Theory of Production and Cost at Depository Financial Institutions." Journal of Finance 32 (4): 1251-1266. 